\title{
Thromboxane A2 receptor antagonist SQ29548 attenuates SH-SY5Y neuroblastoma cell impairments induced by oxidative stress
}

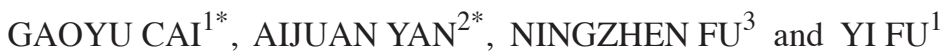 \\ ${ }^{1}$ Department of Neurology, Rui Jin Hospital, Shanghai Jiao Tong University, Shanghai 200025; \\ ${ }^{2}$ Department of Neurology, Xin Hua Hospital, Shanghai Jiao Tong University, Shanghai 200082; \\ ${ }^{3}$ Department of Pancreatic Surgery, Rui Jin College of Clinical Medicine, Rui Jin Hospital, \\ Shanghai Jiao Tong University, Shanghai 200025, P.R. China
}

Received September 28, 2017; Accepted March 21, 2018

DOI: $10.3892 /$ ijmm.2018.3589

\begin{abstract}
Thromboxane A2 receptor (TXA2R) serves a vital role in numerous neurological disorders. Our previous study indicated that SQ29548, an antagonist of TXA2R, attenuated the induced neuron damage in cerebral infarction animals; however, the underlying mechanism remains unknown. Certain studies revealed a new role of TXA2R in the regulation of oxidative stress, which is one of the basic pathological processes in neurological disorders. Thus, the present study attempted to examine whether the inhibition of TXA2R with SQ29548 helped to protect the nerve cells against oxidative stress. SQ29548 was utilized as a TXA2R antagonist, and relevant assays were performed to detect the cell viability, cellular reactive oxygen species (ROS) level, cell apoptosis, expression levels of superoxide dismutase-2 (SOD2), catalase and caspases, and activation of mitogen-activated protein kinase (MAPK) pathways. It was observed that hydrogen peroxide $\left(\mathrm{H}_{2} \mathrm{O}_{2}\right)$ dose-dependently reduced the viability of $\mathrm{SH}-\mathrm{SY} 5 \mathrm{Y}$ cells. In addition, $\mathrm{H}_{2} \mathrm{O}_{2}$ raised the level of ROS in cells, inhibited the expression levels of SOD2 and catalase, and potentially enhanced cell apoptosis and the expression of caspases via activating the MAPK pathways. Pretreatment with SQ29548 not only rescued the viability of SH-SY5Y cells, but also ameliorated the intracellular ROS level and the expression levels of SOD2 and catalase. Furthermore, it decreased the cell apoptosis and the expression of caspases, possibly via the inhibition of MAPK pathways. In conclusion,
\end{abstract}

Correspondence to: Dr Yi Fu, Department of Neurology, Rui Jin Hospital, School of Medicine, Shanghai Jiao Tong University, 197 Rui Jin Er Road, Shanghai 200025, P.R. China

E-mail: fuyiki@sina.com

*Contributed equally

Key words: antagonists, neurons, neuroprotection, oxidative stress, thromboxane $\mathrm{A} 2$ receptor
SQ29548, an antagonist of TXA2R, improved the antioxidant capacities of SH-SY5Y cells and reduced the cell apoptosis through the inhibition of MAPK pathways.

\section{Introduction}

Thromboxane A2 receptor (TXA2R), a member of the G protein-coupled receptor family (1), is broadly distributed in platelets (2), as well as epithelial (3), smooth muscle (4), glial and nerve cells in the brain (5). TXA2R is regarded as a traditional coagulation and inflammation-associated receptor, which is also closely associated with neurological disorders. A previous study of our research group indicated that mutation on TXA2R influenced the morbidity of cerebral infarctions in humans, which may be associated with the changes of coagulation functions (6). Also, it was observed that SQ29548, an antagonist of TXA2R, was able to attenuate the cerebral ischemia-reperfusion damage in mice and improve their behavioral scores (7), thus revealing the potential therapeutic effect of TXA2R antagonists. However, the underlying mechanisms involved remain unclear. A number of studies revealed a new role for TXA2R in regulating the cellular oxidative stress and the consequent apoptotic process (8-10). TXA2R antagonists are reported to ameliorate organic oxidative stress and protect the function of organs (9), which provided a new clue for the treatment of oxidative stress-associated nervous system diseases.

Oxidative stress is an important contributor in the pathogenesis and pathological processes of several neurological disorders $(11,12)$. In general, the cellular reactive oxygen species (ROS) production and the antioxidative defense were observed to be in a dynamic balance. For instance, antioxidative enzymes (13), including superoxide dismutase (SOD) and catalase, efficiently eliminated the ROS produced by cellular respiration. Cerebral infarction (CI) or other neurological disorders lead to an excess of ROS production, which distorts the balance between ROS production and antioxidant defenses. The excessive ROS production results in cellular damage and apoptosis via attacking the lipid, protein and DNA of cells, and activating signaling pathways, such as the 
mitogen-activated protein kinase (MAPK) pathways $(14,15)$. Numerous studies have proven that the elevation of cellular antioxidative stress capacity was beneficial for the limitation of ROS generation, acceleration of ROS elimination, alleviation of ROS damage and inhibition of MAPK signaling pathways to reduce cell death $(13,16)$. Compared with other organs (17), brain tissue is sensitive to oxidative stress damage due to its characteristics of high energy consumption and weak antioxidative stress capacity. Therefore, the identification of a novel effective neuroprotective agent is essential in the prevention and treatment of oxidative stress-associated neurological disorders.

In view of the association between TXA2R and oxidative stress, increasing attention has concentrated on the role of TXA2R and its antagonists in the treatment of oxidative stress-associated neurological disorders and the underlying molecular mechanisms. In the present study, an in vitro oxidative stress model was established in order to investigate whether the TXA2R antagonist SQ29548 regulated the cellular oxidative stress response in nerve cells and determined the mechanisms involved.

\section{Materials and methods}

Reagents. Hydrogen peroxide $\left(\mathrm{H}_{2} \mathrm{O}_{2}\right.$; cat. no. 323381; used for cell experiments), dimethyl sulfoxide (DMSO; cat. no. D2650), poly-D-lysine hydrobromide (cat. no. P6407), nicotinamide adenine dinucleotide (NADH; cat. no. N4505), sodium pyruvate (cat. no. P4562) and Triton X-100 (cat. no. T8787) were purchased from Sigma-Aldrich (Merck KGaA, Darmstadt, Germany). SQ29548 (cat. no. 19025) was obtained from Cayman Chemical Company (Ann Arbor, MI, USA). Bovine serum albumin (BSA; cat. no. 36102ES) was from Yeasen Biotechnology Co.,Ltd. (Shanghai, China). Water-soluble tetrazolium salt (WST-1; cat. no. C0035), 2',7'-dichlorofluorescin diacetate (DCFH-DA; cat. no. S0033) and DAPI (cat. no. C1002) were purchased from Beyotime Institute of Biotechnology (Shanghai, China). ApoScreen Annexin V Apoptosis-phycoerythrin (PE) kit (cat. no. 10010-09) was obtained from Southern Biotech (Birmingham, AL, USA). Terminal deoxynucleotidyl transferase dUTP nick end labeling (TUNEL; cat. no. TUN002) staining reagents were purchased from Mai bio (Shanghai, China). An antibody against TXA2R was from Santa Cruz Biotechnology, Inc. (Dallas, TX, USA; cat. no. sc-30036). Antibodies against c-Jun N-terminal kinases (JNK; cat. no. 9926), extracellular signal-regulated kinase (ERK; cat. no. 9926), p38 (cat. no. 9926), phosphorylated (p)-JNK (cat. no. 9910), p-ERK (cat. no. 9910), p-p38 (cat. no. 9910), cleaved caspase3 (cat. no. 9661), caspase3 (cat. no. 9662), cleaved caspase9 (cat. no. 9501), caspase9 (cat. no. 9502) and $\beta$-tubulin (cat. no. 15115), as well as the anti-rabbit horseradish peroxidase-conjugated secondary antibody (cat. no. 7074), were purchased from Cell Signaling Technology, Inc. (Danvers, MA, USA). Antibodies for SOD2 (cat. no. ab13534) and catalase (cat. no. ab16731) were from Abcam (Cambridge, MA, USA). An antibody for NeuN (cat. no. MAB377) was from EMD Millipore (Billerica, MA, USA). The Alexa-594 antibody (cat. no. A21203; Invitrogen), TRIzol reagent (cat. no. 15596026) and BCA protein detection kit (cat. no. 23225) were purchased from Thermo Fisher
Scientific, Inc. (Waltham, MA, USA). Paraformaldehyde (PFA; cat. no. 80096618), potassium phosphate (cat. no. 10017518), $30 \%$ hydrogen peroxide (cat. no. 10011208; used for TUNEL staining) from Sinopharm Chemical Reagent Co., Ltd. (Shanghai, China). The primers used in this study were synthesised by Sangon Biotech Co., Ltd. (Shanghai, China).

Cell culture and oxidative stress model. SH-SY5Y cells were acquired from the Cell Bank of Shanghai Institute of Biochemistry and Cell Biology, Chinese Academy of Sciences (Shanghai, China). SH-SY5Y cells were incubated in the Dulbecco's modified Eagle's medium (DMEM; HyClone; GE Healthcare, Logan, UT, USA) supplemented with $10 \%$ fetal bovine serum (FBS; HyClone; GE Healthcare) and $1 \%$ penicillin-streptomycin (Invitrogen; Thermo Fisher Scientific, Inc.) at $37^{\circ} \mathrm{C}$ in a $5 \% \mathrm{CO}_{2}$ incubator. When the cell confluence reached $80 \%$, cells were collected and transferred into 96-well plates at a cell density of $2 \times 10^{4}$ cells/well for WST-1 assay, while 24 -well plates $\left(1 \times 10^{5}\right.$ cells/well) were used for DCFH-DA, TUNEL and lactate dehydrogenase (LDH) assays, and 6 -well plates $\left(3 \times 10^{5}\right.$ cells/well) were used for western blot analysis, reverse transcription-quantitative polymerase chain reaction (RT-qPCR) and flow cytometry. Subsequently, the cells were incubated in DMEM without sodium pyruvate with $10 \%$ FBS and $1 \%$ penicillin-streptomycin for $24 \mathrm{~h}$. All the plates used were pretreated with poly-D-lysine hydrobromide solution $(0.1 \mathrm{mg} / \mathrm{ml})$ for $24 \mathrm{~h}$ and then washed three times with phosphate-buffered saline (PBS; HyClone; GE Healthcare). A total of $24 \mathrm{~h}$ after the cells transferred to the plates, DMSO was added to the control group and SQ29548 (dissolved in DMSO) in different concentrations were added to the treatment groups. After 2-h treatment, the cells were washed three times with PBS. Next, the cells were treated with or without $\mathrm{H}_{2} \mathrm{O}_{2}$ in different concentrations in the medium for $1 \mathrm{~h}$, followed by washing three times with PBS. Finally, DMEM (without sodium pyruvate) with $10 \%$ FBS and $1 \%$ penicillin-streptomycin was used for subsequent culture and experiments.

WST-1 assay. A WST-1 assay was utilized to detect the cell viability, according to the protocol provided by the manufacturer. After transferring the cells to the plates for $24 \mathrm{~h}$, the cells were treated with SQ29548 $(0,0.1,0.5,1.0$ and $10 \mu \mathrm{M})$ for $2 \mathrm{~h}$ or treated with $\mathrm{H}_{2} \mathrm{O}_{2}(0,0.05,0.1,0.2,0.5$ and $1.0 \mathrm{mM})$ for $1 \mathrm{~h}$ or treated with $\mathrm{H}_{2} \mathrm{O}_{2}(0,0.1 \mathrm{mM})$ for $1 \mathrm{~h}$ following pretreatment with SQ29548 $(0,0.1,0.5,1.0$ and $10 \mu \mathrm{M})$ for $2 \mathrm{~h}$. Subsequent to the incubation for $24 \mathrm{~h}, 10 \mu \mathrm{l}$ WST-1 solution was added to the SH-SY5Y cells. After $1 \mathrm{~h}$ of incubation at $37^{\circ} \mathrm{C}$, a microplate reader (Bio-Rad Laboratories, Inc., Hercules, CA, USA) was used to measure the absorbance of each well at $450 \mathrm{~nm}$.

LDH assay. An LDH assay was conducted as reported previously (18). The cells were treated with $\mathrm{H}_{2} \mathrm{O}_{2}(0,0.1 \mathrm{mM})$ for $1 \mathrm{~h}$ after pretreated with SQ29548 $(0,0.1,1.0 \mu \mathrm{M})$ for $2 \mathrm{~h}$. After $24 \mathrm{~h}$ of incubation, $150 \mu \mathrm{l}$ culture medium of post-treated SH-SY5Y cells was collected and added into 96-well plates. Next, $150 \mu \mathrm{l}$ reaction buffer containing $500 \mathrm{mM}$ potassium phosphate, $7.5 \mathrm{mM}$ sodium pyruvate and $1.5 \mathrm{mM}$ NADH was added successively and the absorbance of each well at $340 \mathrm{~nm}$ was measured over $30 \mathrm{sec}$ with the microplate reader. 
Intracellular ROS level assay. The intracellular ROS level was detected with DCFH-DA reagents. The cells were treated with $\mathrm{H}_{2} \mathrm{O}_{2}(0$ or $0.1 \mathrm{mM})$ for $1 \mathrm{~h}$ following pretreatment with SQ29548 $(0,0.1,1.0 \mu \mathrm{M})$ for $2 \mathrm{~h}$. Treated SH-SY5Y cells were washed three times with PBS after 1-h incubation. Next, $200 \mu \mathrm{l}$ DMEM (without sodium pyruvate, serum and antibiotics) with $10 \mu \mathrm{M}$ DCFH-DA was added into each well. After $20 \mathrm{~min}$ of incubation at $37^{\circ} \mathrm{C}$, DMEM (without sodium pyruvate, serum and antibiotics) was used to wash the cells for three times. The plates were then observed with an inverted fluorescence microscope (Leica Microsystems GmbH, Wetzlar, Germany) at an excitation wavelength of $488 \mathrm{~nm}$ and an emission wavelength of $525 \mathrm{~nm}$. All the data were subjected to fluorescence intensity analysis with Image J software, version 1.14 (National Institutes of Health, Bethesda, MA, USA).

Annexin V-PE and 7-aminoactinomycin D (7-AAD) double-staining assay. Flow cytometry was performed as reported previously (19). The cells were treated with $\mathrm{H}_{2} \mathrm{O}_{2}$ $(0,0.1 \mathrm{mM})$ for $1 \mathrm{~h}$ following pretreatment with SQ29548 (0, 0.1, $1.0 \mu \mathrm{M})$ for $2 \mathrm{~h}$. Treated SH-SY5Y cells were digested after $1-\mathrm{h}$ incubation, and $10 \mu \mathrm{l}$ of which was then used for cell counting with Fuchs-Rosenthal counting chambers. Subsequently, the cells were centrifuged at $74 \mathrm{x}$ g for $4 \mathrm{~min}$ at $4^{\circ} \mathrm{C}$. Centrifuged cells were resuspended with cold $1 \mathrm{X}$ Annexin binding buffer to obtain a density of a $1 \times 10^{6}$ cells $/ \mathrm{ml}$. A total of $10 \mu \mathrm{l}$ Annexin V-PE was added to $100 \mu \mathrm{l}$ cell suspension and the cell suspension was then incubated in the dark for $15 \mathrm{~m}$ at $4^{\circ} \mathrm{C}$. After the incubation, $380 \mu \mathrm{l}$ cold $1 \mathrm{X}$ Annexin binding buffer and $10 \mu 17$-AAD were added to the cell suspension at $4^{\circ} \mathrm{C}$, and the cell suspension was immediately subjected to apoptosis assay by flow cytometry (Bio-Rad Laboratories, Inc.).

TUNEL staining. The cells were treated with $\mathrm{H}_{2} \mathrm{O}_{2}(0,0.1 \mathrm{mM})$ for $1 \mathrm{~h}$ following pretreatment with SQ29548 $(0,0.1,1.0 \mu \mathrm{M})$ for $2 \mathrm{~h}$. After $1 \mathrm{~h}$ of incubation, the treated SH-SY5Y cells were fixed with $4 \%$ PFA for $10 \mathrm{~m}$ at $4{ }^{\circ} \mathrm{C}$ and sealed with methanol containing $3 \% \mathrm{H}_{2} \mathrm{O}_{2}$, and $0.3 \%$ Triton $\mathrm{X}-100$ was then used for membrane rupture. Next, $50 \mu 1$ In Situ Cell Death reagent was added to each slide, and then cells were incubated without light exposure for $60 \mathrm{~min}$. Subsequent to $150 \mu \mathrm{l}$ DAPI staining (1:300) for $3 \mathrm{~min}$ at room temperature, slides were sealed and observed with a confocal fluorescence microscope (Leica Microsystems GmbH).

RT- $q P C R$. The cells were treated with $\mathrm{H}_{2} \mathrm{O}_{2}(0,0.1 \mathrm{mM})$ for $1 \mathrm{~h}$ following pretreatment with SQ29548 $(0,0.1 \mu \mathrm{M})$ for $2 \mathrm{~h}$. After $12 \mathrm{~h}$ of incubation, total RNA was extracted from the treated SH-SY5Y cells with TRIzol reagent and was reverse transcribed into cDNA with PrimeScript RT reagent kit (Takara Bio, Inc., Otsu, Japan), as previously described (20). qPCR was subsequently implemented on an Applied Biosystems 7500 Real-Time PCR system (Thermo Fisher Scientific, Inc.) using a SYBR Green kit (Takara Bio, Inc.) under the following conditions: Denaturation at $95^{\circ} \mathrm{C}$ for $10 \mathrm{sec}$, followed by 40 cycles at $95^{\circ} \mathrm{C}$ for $5 \mathrm{sec}$ and at $60^{\circ} \mathrm{C}$ for $30 \mathrm{sec}$. The primes used in qPCR were as follows: SOD2, 5'-GGTGGTCATATCAATCATAG-3' (forward) and 5'-AGTGGAATAAGGTTTGTTGT-3' (reverse); catalase, 5'-TTAATCCATTCGATCTCACC-3' (forward) and 5'-GGCGGTGAGTGTCAGGATAG-3' (reverse); GAPDH,
5'-TCTTCTTTTGCGTCGCCAG-3' (forward) and 5'-GGG GGCAGAGATGATGACC-3' (reverse). GAPDH served as the loading control. All the data were analyzed with the comparative threshold cycle $(\mathrm{Cq})$ method (21).

Western blot analysis. The cells were treated with $\mathrm{H}_{2} \mathrm{O}_{2}$ $(0,0.1 \mathrm{mM})$ for $1 \mathrm{~h}$ following pretreatment with SQ29548 $(0,0.1 \mu \mathrm{M})$ for $2 \mathrm{~h}$. Protein was extracted with standard lysis buffer (Cell Signaling Technology, Inc.). Following purification, a BCA protein detection kit was used for protein concentration measurement. Equal amounts of extracted protein $(30 \mu \mathrm{g})$ were separated with $10 \%$ SDS-PAGE. Subsequently the proteins were transferred to nitrocellulose membranes at $300 \mathrm{~mA}$ for $90 \mathrm{~min}$. After $1 \mathrm{~h}$ of incubation in $5 \% \mathrm{BSA}$ for blocking at room temperature, membranes were incubated at $4^{\circ} \mathrm{C}$ overnight with primary antibodies diluted at 1:1,000. Subsequent to washing three times with TBST, anti-rabbit horseradish peroxidase-conjugated secondary antibody diluted at 1:5,000 was added for 1-h incubation at room temperature. Following further washing with TBST for three times, the specific bands were visualized with an enhanced chemiluminescence reagent (Thermo Fisher Scientific, Inc.) in a gel imaging system (Tanon Science \& Technology Co., Ltd., Shanghai, China). ImageJ software was applied for gray analysis of the data.

Statistical analysis. All the data were analyzed with GraphPad Prism software, version 5.0 (GraphPad Software, Inc., La Jolla, CA, USA). Comparison between two groups was performed with an unpaired t-test, while comparison among several groups was performed with one-way analysis of variance, followed by a Student-Newman-Keuls test. All the data are expressed as the mean \pm standard error of the mean. $\mathrm{P}<0.05$ was regarded as an indicator of a statistically significant difference.

\section{Results}

SQ29548 attenuates the decrease in the viability of SH-SY5Y cells induced by $\mathrm{H}_{2} \mathrm{O}_{2}$. Previous studies have reported $(5,22)$ the expression of TXA2R on the membrane of nerve cells. In the present study, the expression of TXA2R on the surface of SH-SY5Y cells was confirmed by staining with TXA2R antibody and DAPI (Fig. 1A). Subsequently, to evaluate the function of SQ29548 and $\mathrm{H}_{2} \mathrm{O}_{2}$ on SH-SY5Y cell viability, a WST-1 assay was applied after cells were treated with different SQ29548 and $\mathrm{H}_{2} \mathrm{O}_{2}$ concentrations. It was observed that, compared with the untreated control group, treatment with DMSO or with $0.1,0.5,1.0$ and $10 \mu \mathrm{M}$ SQ29548 resulted in cell viability of $98.86 \pm 4.55,99.15 \pm 2.90,95.97 \pm 2.55$, $100.20 \pm 1.86$ and $95.33 \pm 4.03 \%$, respectively (Fig. 1B). No statistically significant difference was observed among these groups ( $\mathrm{P}>0.05)$, indicating that SQ29548 did not evidently affected the SH-SY5Y cell viability. However, treatment with $0.05,0.1,0.2,0.5$ and $1.0 \mathrm{mM} \mathrm{H}_{2} \mathrm{O}_{2}$ reduced the $\mathrm{SH}-\mathrm{SY} 5 \mathrm{Y}$ cell viability to $83.01 \pm 1.52,31.91 \pm 1.85,28.16 \pm 1.44,25.32 \pm 1.44$ and $23.30 \pm 1.65 \%$, respectively, compared with the untreated control group (Fig. 1C). Considering other relevant findings $(17,23)$, the concentration of $0.1 \mathrm{mM} \mathrm{H}_{2} \mathrm{O}_{2}$ was selected for subsequent experiments. 
A

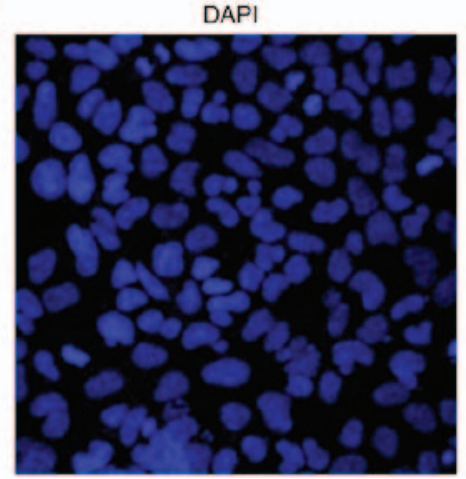

B

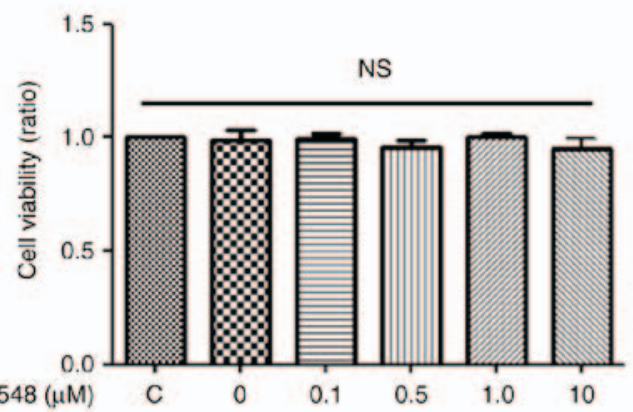

D

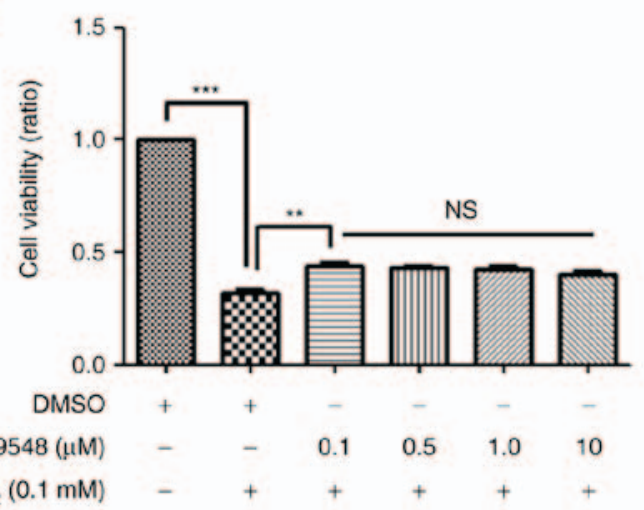

TXA2R

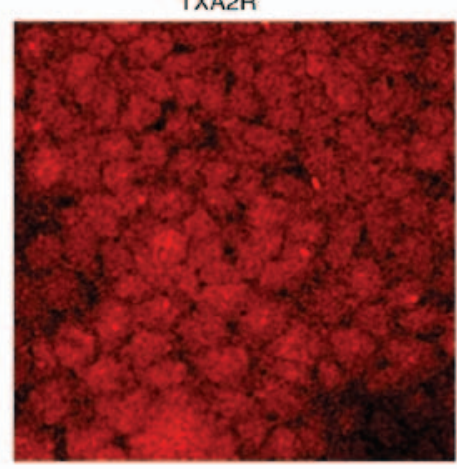

C

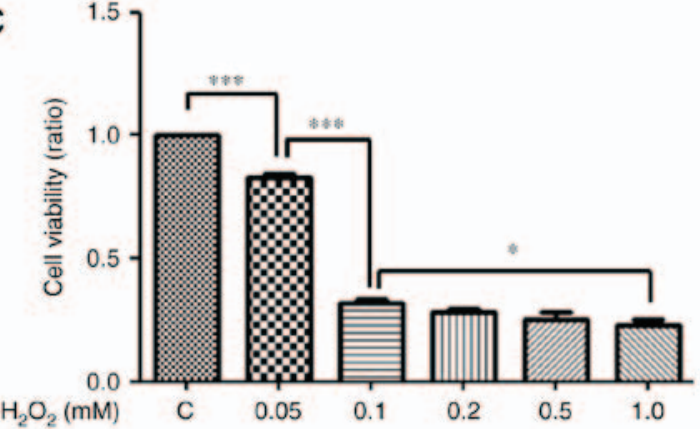

E

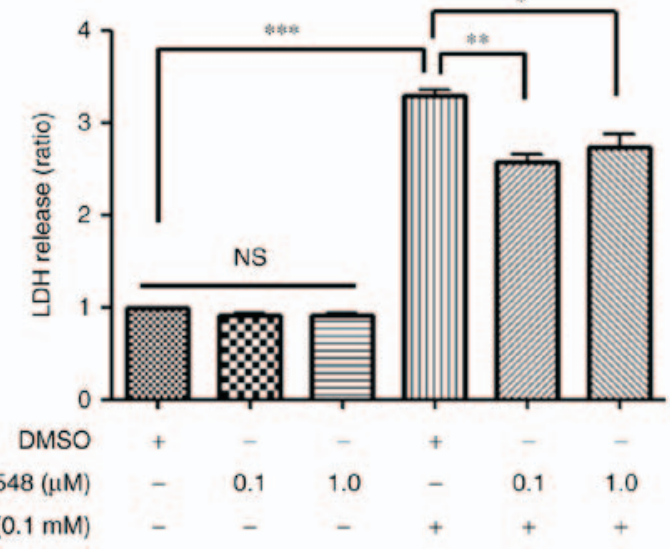

Figure 1. TXA2R existed on the surface of SH-SY5Y cells and SQ29548 inhibited the decrease of cell viability in SH-SY5Y cells induced by $\mathrm{H}_{2} \mathrm{O}_{2}$. (A) TXA2R was distributed on the surface of SH-SY5Y cells. A WST-1 assay was used to examine the changes in cell viability subsequent to treatment with (B) $\mathrm{SQ} 29548$, (C) $\mathrm{H}_{2} \mathrm{O}_{2}$ and (D) SQ29548 and $\mathrm{H}_{2} \mathrm{O}_{2}$ combined. (E) The LDH release of SH-SY5Y cells treated with SQ29548 and $\mathrm{H}_{2} \mathrm{O}_{2}$. Data are expressed as the mean \pm standard error of the mean. $\mathrm{n}=3$. ${ }^{*} \mathrm{P}<0.05,{ }^{* *} \mathrm{P}<0.01$ and ${ }^{* * *} \mathrm{P}<0.001$. TXA2R, thromboxane $\mathrm{A} 2$ receptor; $\mathrm{H}_{2} \mathrm{O}_{2}$, hydrogen peroxide; DMSO, dimethyl sulfoxide; n.s., no significant difference.

A

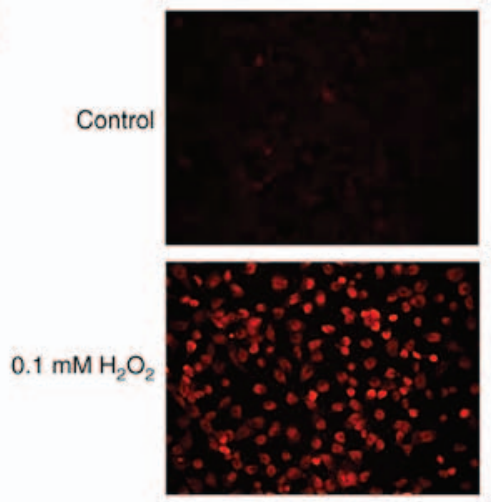

DMSO
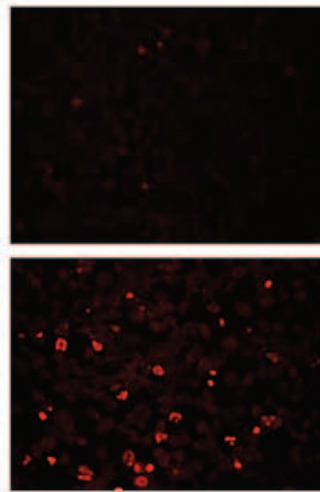

$0.1 \mu \mathrm{M} \mathrm{SQ} 29548$
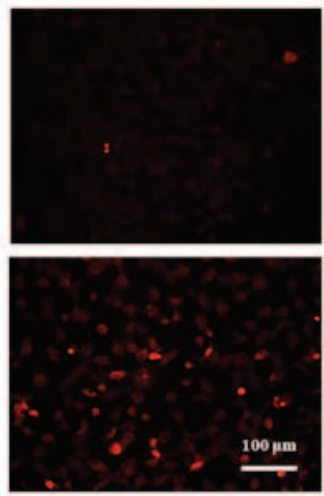

$1.0 \mu \mathrm{M} \mathrm{SQ} 28548$
B

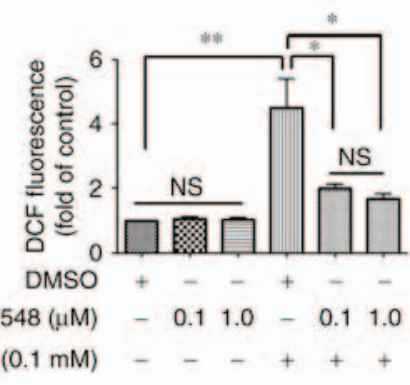

Figure 2. SQ29548 reduced the ROS level in SH-SY5Y cells treated with $\mathrm{H}_{2} \mathrm{O}_{2}$. (A) DCFH-DA was performed to evaluate the intracellular ROS level. (B) Comparisons of DCF fluorescence intensity quantization among all the groups. The results are shown as the mean \pm standard error of the mean (n=3). ${ }^{\prime \prime} \mathrm{P}<0.05$ and ${ }^{* *} \mathrm{P}<0.01$. ROS, reactive oxygen species; $\mathrm{H}_{2} \mathrm{O}_{2}$, hydrogen peroxide; DCFH-DA, 2',7'-dichlorofluorescin diacetate; DMSO, dimethyl sulfoxide; n.s., no significant difference. 


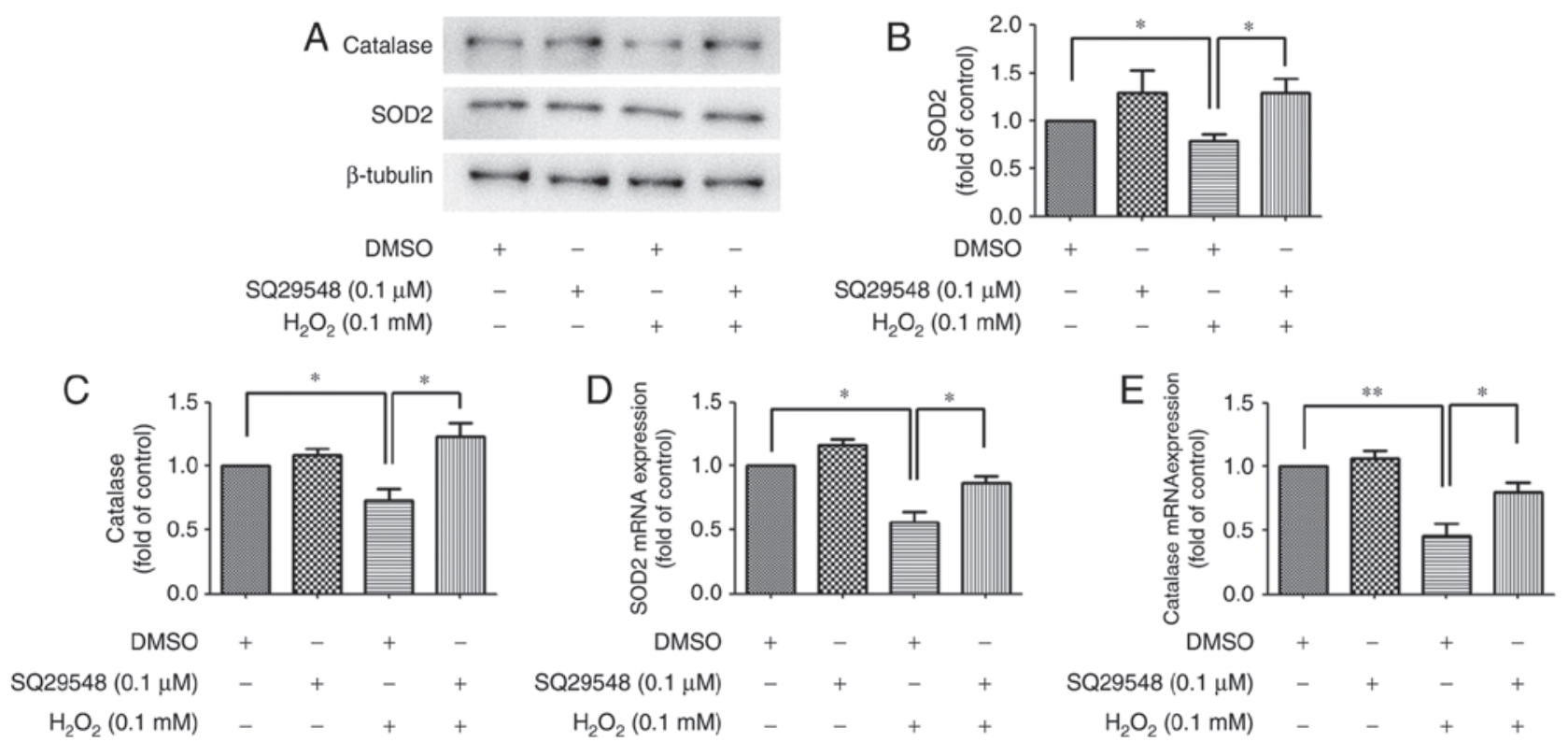

Figure 3. SQ29548 ameliorated the decreases in SOD2 and catalase levels induced by $\mathrm{H}_{2} \mathrm{O}_{2}$ in SH-SY5Y cells. (A) Western blot analysis evaluated the protein expression levels of SOD2 and catalase. Gray value quantification of (B) SOD2 and (C) catalase expression levels. (D) SOD2 and (E) catalase mRNA expression levels are shown. Results are expressed as the mean \pm standard error of the mean $(\mathrm{n}=3)$. ${ }^{*} \mathrm{P}<0.05,{ }^{* *} \mathrm{P}<0.01$ and ${ }^{* * *} \mathrm{P}<0.001$. SOD2, superoxide dismutase-2; $\mathrm{H}_{2} \mathrm{O}_{2}$, hydrogen peroxide; DMSO, dimethyl sulfoxide; n.s., no significant difference.

An oxidative stress model was then established in SH-SY5Y cells by $\mathrm{H}_{2} \mathrm{O}_{2}$ treatment $(0.1 \mathrm{mM}) . \mathrm{H}_{2} \mathrm{O}_{2}$-induced cells that were also pretreated with $0.1,0.5,1.0$ and $10 \mu \mathrm{M}$ SQ29548 for $2 \mathrm{~h}$ exhibited improved viability of $44.29 \pm 1.40,43.28 \pm 1.07$, $42.32 \pm 2.03$ and $40.27 \pm 1.29 \%$, respectively. By contrast, the cell viability of the $\mathrm{H}_{2} \mathrm{O}_{2}$-treated only group was $32.27 \pm 1.54 \%$, compared with that of the control group (Fig. 1D). The results indicated the protective effect of SQ29548 on cell viability. Furthermore, this protective effect was independent of the concentration of SQ29548.

The LDH assay demonstrated that, in the $\mathrm{H}_{2} \mathrm{O}_{2}$-treated only group, the LDH release was $3.30 \pm 0.06$-fold that of the control group; by contrast, 0.1 and $1.0 \mu \mathrm{M} \mathrm{SQ} 29548$ significantly decreased the LDH release to $2.57 \pm 0.09$-fold and 2.74 \pm 0.14 -fold that of the control, respectively (Fig. 1E). Therefore, the protective effect of SQ29548 on cell viability was further confirmed.

SQ29548 reduces the intracellular ROS level in SH-SY5Y cells induced by $\mathrm{H}_{2} \mathrm{O}_{2}$. A DCFH-DA assay was performed to evaluate the effect of SQ29548 on the intracellular ROS level of SH-SY5Y cells (Fig. 2A). $\mathrm{H}_{2} \mathrm{O}_{2}$ increased the SH-SY5Y intracellular ROS level to $4.95 \pm 0.97$-fold that of the control group (Fig. 2B). However, pretreatment with 0.1 and $1.0 \mu \mathrm{M}$ SQ29548 decreased the intracellular ROS level to $2.01 \pm 0.10$-fold and $1.69 \pm 0.16$-fold, respectively, of the control group level (Fig. 2B). Thus, SQ29548 reduced the ROS generation in SH-SY5Y cells induced by $\mathrm{H}_{2} \mathrm{O}_{2}$.

SQ29548 ameliorates the decrease in SOD2 and catalase levels in $\mathrm{SH}-\mathrm{SY} 5 \mathrm{Y}$ cells induced by $\mathrm{H}_{2} \mathrm{O}_{2}$. To determine whether the change of ROS level was mediated by the regulatory effect of SQ29548 on intracellular antioxidant proteins, the intracellular SOD2 and catalase protein and mRNA levels were evaluated. Upon treatment with $\mathrm{H}_{2} \mathrm{O}_{2}$, the protein levels of SOD2 (Fig. 3A and B) and catalase (Fig. 3A and C) were significantly inhibited, while their mRNA levels was also decreased to $56.05 \pm 7.95 \%$ (Fig. 3D) and $45.83 \pm 9.70 \%$ (Fig. 3E) of the control group levels, respectively. By contrast, pretreatment with SQ29548 significantly ameliorated the $\mathrm{H}_{2} \mathrm{O}_{2}$-induced decrease in the protein levels of SOD2 and catalase (Fig. 3B and C), while the mRNA levels were rescued to $85.70 \pm 5.75 \%$ (Fig. 3D) and $80.17 \pm 7.02 \%$ (Fig. 3E) of the control group levels, respectively. Therefore, SQ29548 appeared to ameliorate the $\mathrm{H}_{2} \mathrm{O}_{2}$-induced decrease in the expression levels of SOD2 and catalase in SH-SY5Y cells, and to improve the antioxidative stress capacities of SH-SY5Y cells.

SQ29548 reduces the apoptosis of SH-SY5Y cells induced by $\mathrm{H}_{2} \mathrm{O}_{2}$. Oxidative stress may result in cell damage and consequently induce cell apoptosis. To investigate the impact of SQ29548 on SH-SY5Y cell apoptosis, Annexin V-PE/7-AAD double-staining assay (Fig. 4A-C) and TUNEL staining (Fig. 4D and E) were selected to estimate the cell apoptosis. The Annexin V-PE/7-AAD double-staining assay revealed that $\mathrm{H}_{2} \mathrm{O}_{2}$ increased the ratio of early-stage and late-stage apoptosis in SH-SY5Y cells to $26.23 \pm 2.46$ and $15.4 \pm 1.89 \%$, as compared with the ratios of $5.82 \pm 1.31$ and $2.07 \pm 1.07 \%$ in the control group, respectively (Fig. 4B and C). However, pretreatment with 0.1 and $1.0 \mu \mathrm{M}$ SQ29548 significantly abated the early-stage apoptosis cell ratio to $18.18 \pm 1.56$ and $16.33 \pm 1.50 \%$, respectively (Fig. 4B), while the late-stage apoptosis cell ratio was at $8.85 \pm 0.57$ and $8.58 \pm 1.05 \%$, respectively (Fig. 4C). No significant difference was observed between the 0.1 and $1.0 \mu \mathrm{M} \mathrm{SQ} 29548$ groups ( $\mathrm{P}>0.05)$.

TUNEL staining was also applied as a detector of cell apoptosis. Compared with the control group, $\mathrm{H}_{2} \mathrm{O}_{2}$ markedly raised the ratio of TUNEL-positive cells to $15.21 \pm 2.71 \%$ from $0.90 \pm 0.1 \%$. Pretreatment with 0.1 and $1.0 \mu \mathrm{M}$ SQ29548 significantly reduced the ratio of TUNEL-positive cells to $9.19 \pm 0.82$ 


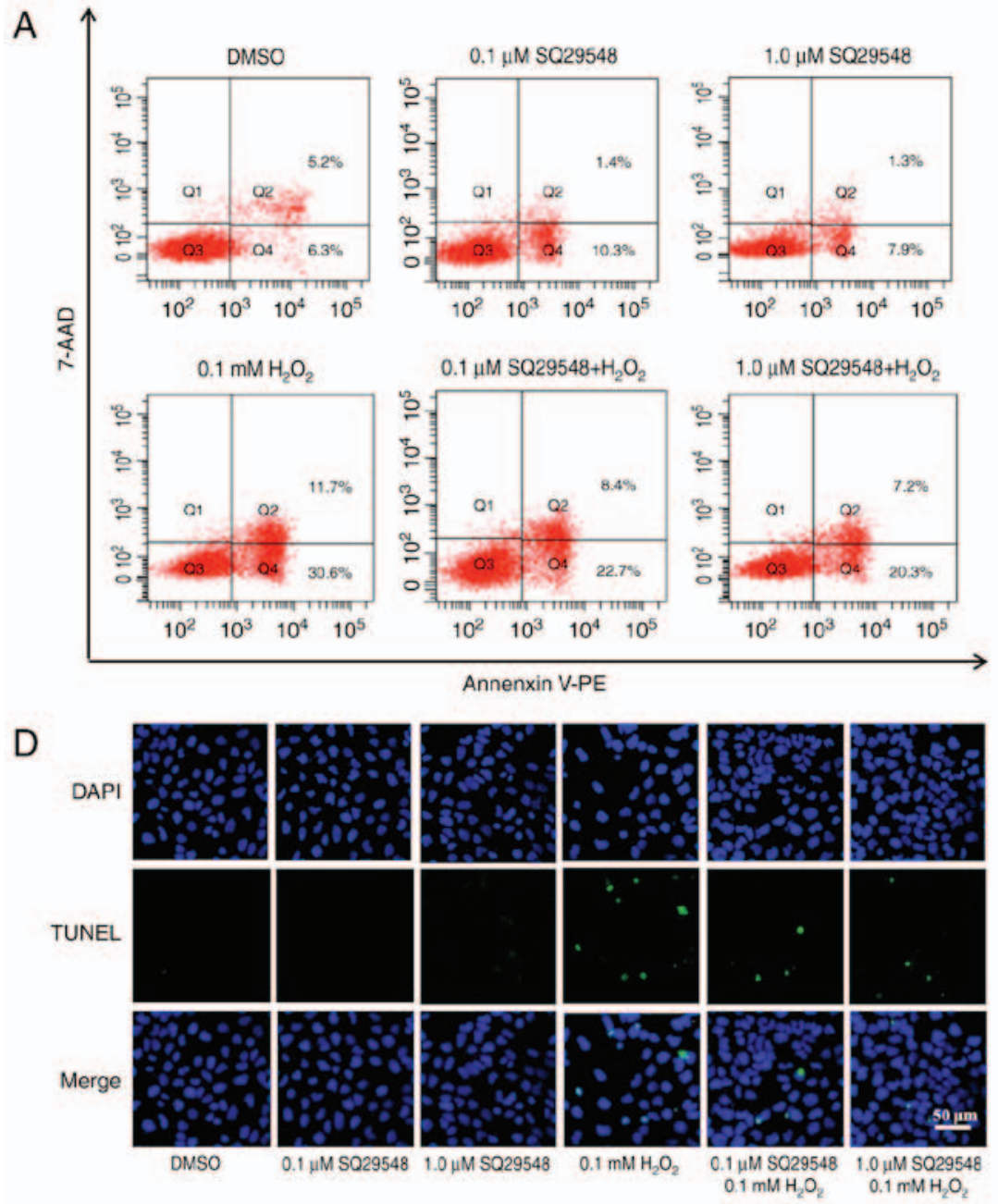

B

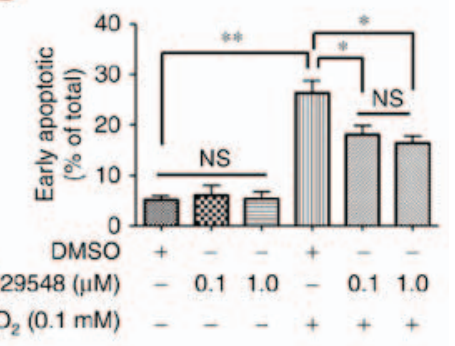

C

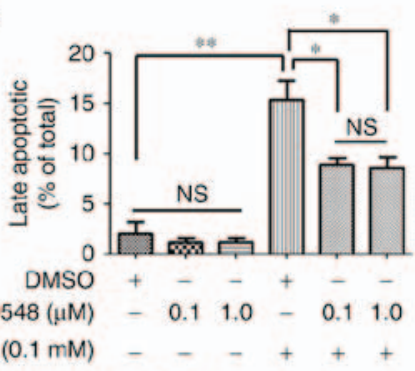

E

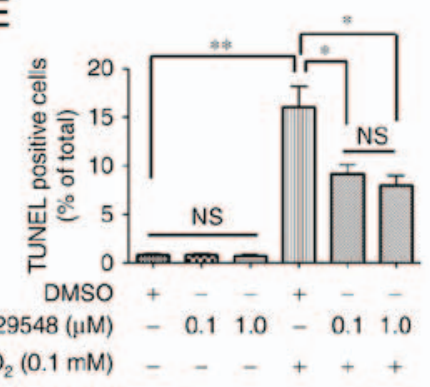

Figure 4. SQ29548 reduced the cell apoptosis of SH-SY5Y cells induced by $\mathrm{H}_{2} \mathrm{O}_{2}$. (A) Flow cytometry analysis using Annexin V-PE/7-AAD double staining. Normal cells are observed in Q3 quadrant, early-stage apoptotic cells in Q4, late-stage apoptotic cells in Q2 and cell debris in Q1. Cell ratio of (B) early-stage and (C) late-stage apoptotic cells among all the groups. (D) TUNEL staining of the apoptotic cells. (E) Percentage of TUNEL-positive cells. Results are expressed as the mean \pm standard error of the mean $(n=3)$. ${ }^{*} \mathrm{P}<0.05$ and ${ }^{* *} \mathrm{P}<0.01 . \mathrm{H}_{2} \mathrm{O}_{2}$, hydrogen peroxide; DMSO, dimethyl sulfoxide; PE, phycoerythrin; 7-AAD, 7-aminoactinomycin D; TUNEL, terminal deoxynucleotidyl transferase dUTP nick end labeling; n.s., no significant difference.

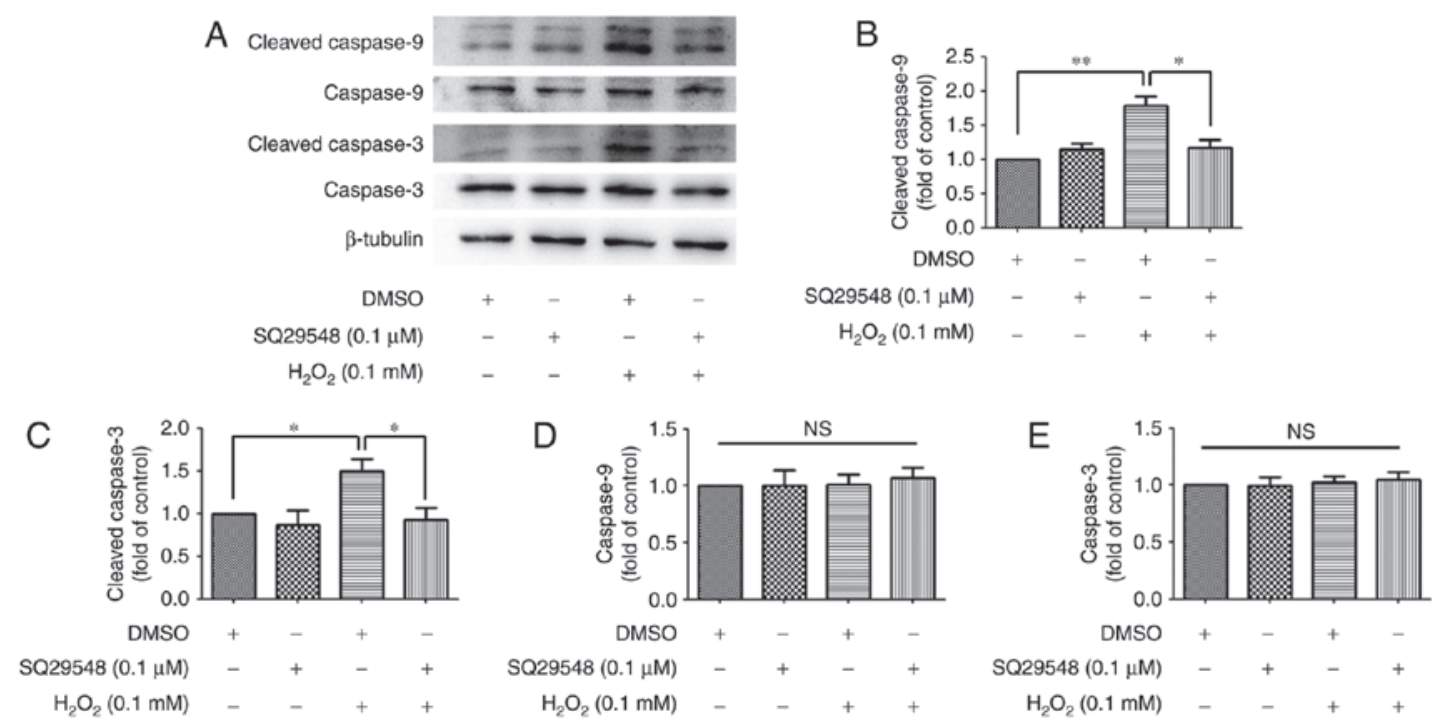

Figure 5. SQ29548 inhibited the expression levels of cleaved caspase9 and cleaved caspase3 in SH-SY5Y cells induced by $\mathrm{H}_{2} \mathrm{O}_{2}$. (A) Western blot analysis was performed to evaluate the expression levels of cleaved caspase9, caspase9, cleaved caspase3 and caspase3. Gray value quantification of (B) cleaved caspase9/total caspase9, (C) cleaved caspase3/total caspase3, (D) caspase9 and (E) caspase3. No significant difference was observed in the expression of total caspase 9 and total caspase 3 among the different groups. Results are expressed as the mean \pm standard error of the mean $(n=3)$. ${ }^{*} \mathrm{P}<0.05$ and ${ }^{* *} \mathrm{P}<0.01 . \mathrm{H}_{2} \mathrm{O}_{2}$, hydrogen peroxide; DMSO, dimethyl sulfoxide. 


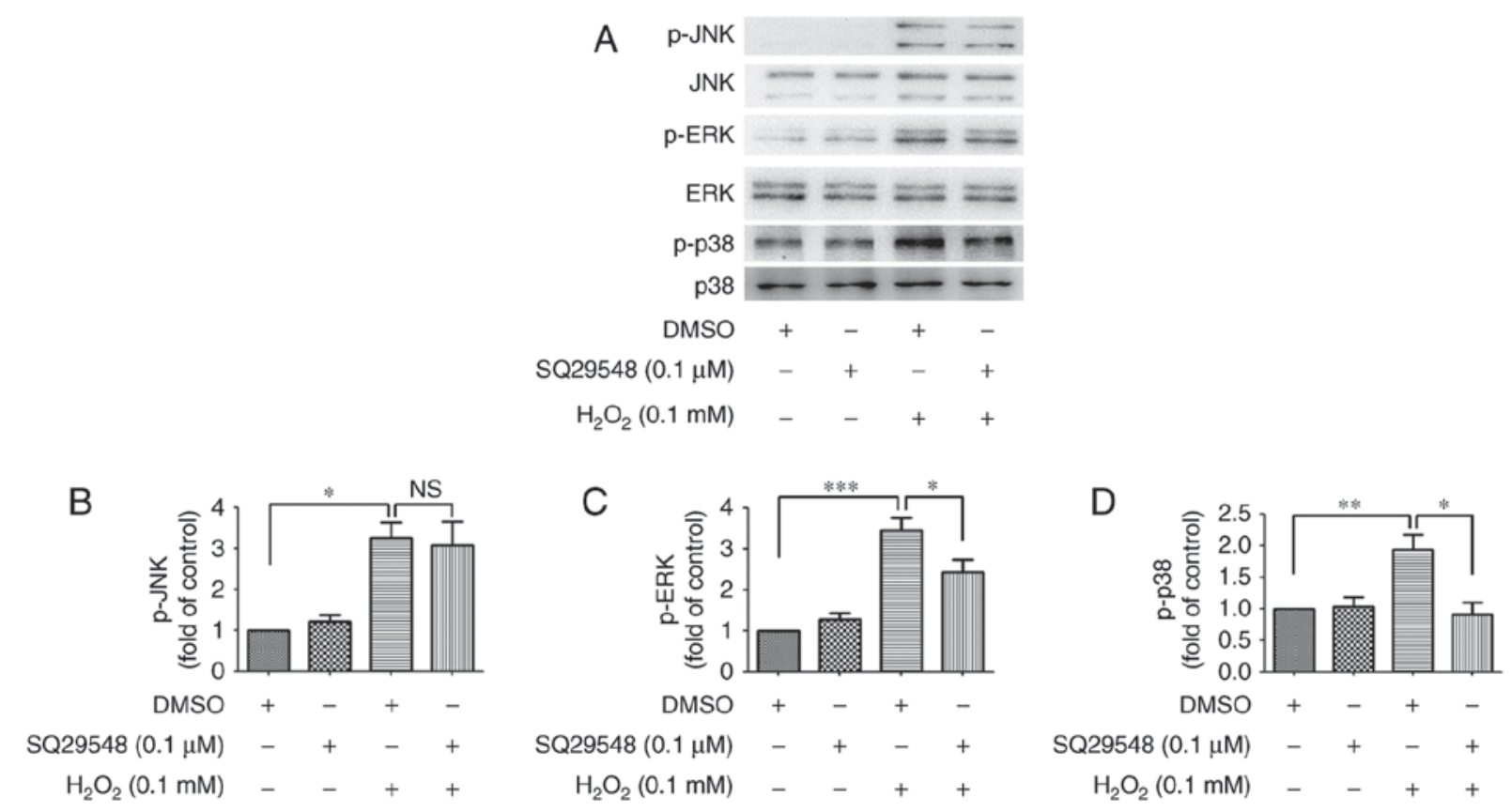

Figure 6. SQ29548 inhibited the activation of ERK and p38 signaling pathways in SH-SY5Y cells induced by $\mathrm{H}_{2} \mathrm{O}_{2}$. (A) Western blot analysis results on the expression levels of p-JNK, JNK, p-ERK, ERK, p-p38 and p38. (B) Gray value quantification of (B) p-JNK/total JNK, (C) p-ERK/total ERK and (D) p-p38/total p38. No significant difference was observed in the expression levels of total JNK, ERK and p38 among the groups. Results are expressed as the mean \pm standard error of the mean $(\mathrm{n}=3) .{ }^{*} \mathrm{P}<0.05,{ }^{* *} \mathrm{P}<0.01$ and ${ }^{* * *} \mathrm{P}<0.001$. JNK, c-Jun $\mathrm{N}$-terminal kinases; ERK, extracellular signal-regulated kinase; p-, phosphorylated; $\mathrm{H}_{2} \mathrm{O}_{2}$, hydrogen peroxide; DMSO, dimethyl sulfoxide; n.s., no significant difference.

and $8.00 \pm 1.00 \%$, respectively (Fig. 4D and E), indicating that SQ29548 reduced the cell apoptosis induced by $\mathrm{H}_{2} \mathrm{O}_{2}$.

SQ29548 inhibits cleaved caspase expression in SH-SY5Y cells induced by $\mathrm{H}_{2} \mathrm{O}_{2}$. Caspases are typical apoptosis-associated proteins, whose cleaved products promote cell apoptosis. The present study attempted to determine how SQ29548 affected the expression of caspases and their cleaved products in $\mathrm{SH}-\mathrm{SY} 5 \mathrm{Y}$ cells induced by $\mathrm{H}_{2} \mathrm{O}_{2}$. The results demonstrated that no significant differences existed in the expression levels of caspase 3 and caspase9 among all the groups $(\mathrm{P}>0.05)$, while $\mathrm{H}_{2} \mathrm{O}_{2}$ markedly elevated the expression levels of cleaved caspase9 and cleaved caspase 3 (Fig. 5A). However, SQ29548-pretreated cells exhibited significantly inhibited expression levels of cleaved caspase9 (Fig. 5B) and cleaved caspase3 (Fig. 5C). Thus, SQ29548 possibly inhibited the expression of cleaved caspases.

SQ29548 inhibits ERK and p38 signaling pathway activation in $\mathrm{SH}$-SY5Y cells induced by $\mathrm{H}_{2} \mathrm{O}_{2}$. MAPK pathways participate in a number of cellular physiological processes and regulate cell apoptosis induced by oxidative stress. In order to examine how SQ29548 interfered in MAPK pathways in SH-SY5Y cells induced by $\mathrm{H}_{2} \mathrm{O}_{2}$, the activation of JNK, ERK and p38 signaling pathways was examined (Fig. 6A). It was observed that $\mathrm{H}_{2} \mathrm{O}_{2}$ evidently activated JNK (Fig. 6B), ERK (Fig. 6C) and p38 (Fig. 6D) signaling pathways in SH-SY5Y cells, while SQ29548 pretreatment inhibited the activation of ERK (Fig. 6C) and p38 (Fig. 6D) signaling pathways. Therefore, SQ29548 may protect SH-SY5Y cells against oxidative stress via the inhibition of ERK and p38 signaling pathway activation.

\section{Discussion}

The results of the present study suggested that SQ29548, one of the TXA2R antagonists, was able to improve the antioxidative stress capacities of cells, reduce intracellular ROS levels and attenuate nerve cell apoptosis via the inhibition of ERK and 338 signaling pathway activation.

TXA2R, which is mainly distributed in platelets, has been suggested to be an important membrane receptor in the coagulation and inflammation processes in humans (6). In recent years, it has been reported that TXA2R also exists in nerve cells (5), and participates in the regulation of a series of physiological processes in peripheral and central nervous cells $(5,24,25)$. Our previous study observed that the mutation of TXA2R affected the coagulation system function and further affected the onset of CI (6). Upon the application of SQ29548, an antagonist of TXA2R, ischemia-reperfusion damage of nerve cells and neurological function defects were attenuated in mice, although the underlying mechanism remains unclear (7). Furthermore, recent studies revealed that TXA2R is also involved in other physiological processes. For instance, activated TXA2R was found to inhibit growth factor expression levels in vascular endothelial cells, which further inhibited angiogenesis and vascular development (26). TXA2R was also closely associated with the cellular oxidative stress response. It has been observed that TXA2R participated in the regulation of cellular oxidative stress (8) and induced cell apoptosis (10), while TXA2R antagonists helped to reduce oxidative stress (9). These aforementioned studies indicated that, in certain neurological disorders, TXA2R may participate in the regulation of oxidative stress and the subsequent apoptotic process of nervous cells. Therefore, it is inferred that 
TXA2R antagonists may protect nervous cells through the regulation of cellular oxidative stress.

SH-SY5Y cells were selected in the present study as the in vitro human nerve cell model, while SQ29548 was used as a TXA2R antagonist and $\mathrm{H}_{2} \mathrm{O}_{2}$ was used to simulate oxidative stress in vitro. SH-SY5Y, a neuron cell line, is widely used in studies investigating neurological disorders $(27,28)$ and oxidative stress in nerve cells $(17,28)$. SQ29548 has been proposed to be a specific, reliable and safe TXA2R antagonist (29), and is broadly utilized in studies on TXA2R $(7,25,30,31)$. $\mathrm{H}_{2} \mathrm{O}_{2}$, as one of main ROS products in cellular oxidative stress (32), is typically used to establish an in vitro oxidative stress cell model $(23,33)$. In the current study, SH-SY5Y cells were initially cultured in DMEM; however, due to the well-known role of sodium pyruvate as a $\mathrm{H}_{2} \mathrm{O}_{2}$ scavenger and neuroprotective agent (34), the medium was altered to sodium pyruvate-negative DMEM following the cell planking, in order to minimize the confounder effects. The results revealed that different doses of SQ29548 had no significant effect on the viability of SH-SY5Y cells. However, different concentrations of $\mathrm{H}_{2} \mathrm{O}_{2}$ significantly influence the cell viability, with even a low concentration of $\mathrm{H}_{2} \mathrm{O}_{2}$ exhibiting a strong cytotoxic function. In addition, the present study observed that different doses of SQ29548 effectively protected against the $\mathrm{H}_{2} \mathrm{O}_{2}$-induced inhibition of SH-SY5Y cell viability, and this protective effect was independent of the dose used.

The DCFH-DA experiment conducted in the current study verified that SQ29548 reduced intracellular ROS levels in SH-SY5Y cells treated with $\mathrm{H}_{2} \mathrm{O}_{2}$, which may be associated with the regulation of intracellular antioxidant protein production following TXA2R inhibition. Intracellular antioxidant proteins, including SOD2 and catalase, serve to eliminate excessive ROS in cells (13). Generally, intracellular superoxide anion would be dismutated to $\mathrm{H}_{2} \mathrm{O}_{2}$ by SODs, particularly SOD2, in mitochondria; subsequently, catalase catalyzes $\mathrm{H}_{2} \mathrm{O}_{2}$ to $\mathrm{H}_{2} \mathrm{O}$ and $\mathrm{O}_{2}$ molecules. However, excessive oxidative stress response not only exceeds the elimination capacity of the antioxidant system, but also impairs the antioxidant system and inhibits the expression of antioxidant proteins $(35,36)$. The present study demonstrated decreased protein and mRNA levels of SOD2 and catalase in SH-SY5Y cells treated with $\mathrm{H}_{2} \mathrm{O}_{2}$. However, SQ29548 treatment rescued these decreased levels, protected the antioxidant system and improved the antioxidative stress capacities of SH-SY5Y cells. SQ29548 also significantly reduced the $\mathrm{H}_{2} \mathrm{O}_{2}$-induced cell apoptosis and inhibited the expression levels of cleaved caspase 9 and cleaved caspase 3 . Caspases are apoptosis-associated proteins $(37,38)$, whose cleaved products promote cell apoptosis (38). In addition, the MAPK signaling pathways, which possess numerous roles in cell physiological processes, also participate in the cell apoptosis process induced by oxidative stress $(39,40)$. For instance, it has been reported that, as a member of the MAPK family, the activation of the ERK signaling pathway induced by $\mathrm{H}_{2} \mathrm{O}_{2}$ caused $\mathrm{SH}-\mathrm{SY} 5 \mathrm{Y}$ cell apoptosis, and the inhibition of this pathway improved the cell survival (41). Furthermore, the inhibition of p38 pathway, another MAPK pathway, was reported to be beneficial against cell apoptosis induced by $\mathrm{H}_{2} \mathrm{O}_{2}$ (42). The two aforementioned phenomena may be associated with the ERK (43) and p38 (44) signaling pathways, which participated in the cell apoptosis process and regulated the expression of apoptosis-associated proteins, such as caspases. Similarly, the present study indicated that SQ92548 regulated the ERK and p38 signaling pathway activation in SH-SY5Y cells treated with $\mathrm{H}_{2} \mathrm{O}_{2}$, suggesting that SQ29548 possibly inhibited SH-SY5Y cell apoptosis and the expression of intracellular apoptosis-associated proteins through interfering with the ERK and p38 signaling pathways.

Oxidative stress is a vital pathological process in CI and other neurological disorders (45). Excessive cerebral oxidative stress severely impairs the neurons, thus, it is important to investigate how to protect nerve cells affected by oxidative stress response. In fact, TXA2R is a known therapeutic target in various diseases, and SQ29548 has been reported to protect against ischemia-reperfusion-induced intestinal impairment (46). There are also certain studies indicating that SQ92548 was able to treat the microvascularblood-brain barrier disruption caused by hyperglycemia and TXA2 (47). However, investigation of the association between TXA2R and oxidative stress in nerve cells has not been previously conducted. The present study further verified the potential of TXA2R as a novel therapeutic target in oxidative stress-associated neurological disorders, such as CI. Among oxidative stress studies, drugs such as edaravone (48) and esculetin (49) were demonstrated to be able to protect cells under oxidative stress. Nevertheless, the current study found that the TXA2R antagonist SQ29548 functioned similarly to these drugs.

However, certain issues remain to be solved. For instance, it is unclear whether extending SQ29548 treatment time amplifies the protective effect, whether the long-term inhibition of TXA2R affected the growth and development of neurons, and whether the nerve cell protection function of SQ29548 existed in other disease models. In future studies, we will investigate other in vivo and in vitro models, extend the SQ92548 treatment time and discuss the function of TXA2R antagonists in other neurological disease models. Such investigations are essential in clarifying the therapeutic mechanism of CI and other neurological disorders.

In conclusion, the present study demonstrated that SQ29548, an antagonist of TXA2R, was able to improve the antioxidative stress capacities of SH-SY5Y cells, and reduce cell apoptosis via the inhibition of ERK and p38 signaling pathways. This provided a new basis for the therapy of oxidative stress-associated neurological disorders.

\section{Acknowledgements}

Not applicable.

\section{Funding}

The present study was supported by key basic research grants from the Science and Technology Commission of Shanghai Mnicipality (grant no. 16JC1400500) and the Science and Technology Commission of Shanghai Municipality (grant no. 12ZR1418600).

\section{Availability of data and materials}

The datasets used and/or analyzed during the current study are available from the corresponding author on reasonable request. 


\section{Authors' contributions}

GC and AY designed and performed the experiments, analyzed the data and wrote the paper. GC, AY, NF and YF reviewed and edited the manuscript. All authors read and approved the manuscript.

\section{Ethics approval and consent to participate}

Not applicable.

\section{Consent for publication}

Not applicable.

\section{Competing interests}

The authors declare that they have no competing interests.

\section{References}

1. Miggin SM and Kinsella BT: Expression and tissue distribution of the mRNAs encoding the human thromboxane A2 receptor (TP) alpha and beta isoforms. Biochim Biophys Acta 1425: 543-559, 1998

2. Kassouf N, Ambily A, Watson S, Hassock S, Authi HS, Srivastava S, Watson SP and Authi KS: Phosphatidylinositol-3,4,5-trisphosphate stimulates $\mathrm{Ca}^{2+}$ elevation and Akt phosphorylation to constitute a major mechanism of thromboxane $\mathrm{A}_{2}$ formation in human platelets. Cell Signal 27: $1488-1498,2015$

3. Bode M and Mackman N: Regulation of tissue factor gene expression in monocytes and endothelial cells: Thromboxane A2 as a new player. Vascul Pharmacol 62: 57-62, 2014.

4. Dagher OK, Jaffa MA, Habib A, Ziyadeh FN, Luttrell LM and Jaffa AA: Abstract 133: Mechanistic insights into bradykinin and thromboxane receptors heterodimerization in vascular smooth muscle cells. Arterioscl Thromb Vascul Biol 36: A133, 2016.

5. Sumimoto S, Muramatsu R and Yamashita T: Thromboxane A2 stimulates neurite outgrowth in cerebral cortical neurons via mitogen activated protein kinase signaling. Brain Res 1594: 46-51, 2015.

6. Shao J, Fu Y, Yang W, Yan J, Zhao J, Chen S and Xia W: Thromboxane A2 receptor polymorphism in association with cerebral infarction and its regulation on platelet function. Curr Neurovasc Res 12: 15-24, 2015.

7. Yan A, Zhang T, Yang X, Shao J, Fu N, Shen F, Fu Y and Xia W: Thromboxane A2 receptor antagonist SQ29548 reduces ischemic stroke-induced microglia/macrophages activation and enrichment, and ameliorates brain injury. Sci Rep 6: 35885, 2016.

8. Zhang M, Dong Y, Xu J, Xie Z, Wu Y, Song P, Guzman M, $\mathrm{Wu} \mathrm{J}$ and Zou MH: Thromboxane receptor activates the AMP-activated protein kinase in vascular smooth muscle cells via hydrogen peroxide. Circ Res 102: 328-337, 2008.

9. Xu S, Jiang B, Maitland KA, Bayat H, Gu J, Nadler JL, Corda S, Lavielle G, Verbeuren TJ, Zuccollo A and Cohen RA: The thromboxane receptor antagonist S18886 attenuates renal oxidant stress and proteinuria in diabetic apolipoprotein E-deficient mice. Diabetes 55: 110-119, 2006.

10. Touchberry CD, Elmore CJ, Srinivas S and Wacker MJ: Thromboxane A2 mediates apoptosis in cardiomyocytes via IP3. FASEB J 27: 1122-1128, 2013.

11. Rezzani R, Rodella LF and Bonomini F: Metabolic syndrome, aging and involvement of oxidative stress. Aging Dis 6: 109-120, 2015 .

12. Salim S: Oxidative stress and the central nervous system. J Pharmacol Exp Ther 360: 201-205, 2016.

13. Birben E, Sahiner UM, Sackesen C, Erzurum S and Kalayci O Oxidative stress and antioxidant defense. World Allergy Organ J 5: 9-19, 2012.

14. Manzanero S, Santro T and Arumugam TV: Neuronal oxidative stress in acute ischemic stroke: Sources and contribution to cell injury. Neurochem Int 62: 712-718, 2013.
15. Schieber M and Chandel NS: Ros function in redox signaling and oxidative stress. Curr Biol 24: R453-R462, 2014.

16. Pisoschi AM and Pop A: The role of antioxidants in the chemistry of oxidative stress: A review. Eur J Med Chem 97: 55-74, 2015.

17. Jiang XW, Bai JP,Zhang Q, Hu XL, Tian X,Zhu J, Liu J, Meng WH and Zhao QC: Caffeoylquinic acid derivatives protect SH-SY5Y neuroblastoma cells from hydrogen peroxide-induced injury through modulating oxidative status. Cell Mol Neurobiol 37: 499-509, 2017.

18. Shao J, Liu T, Xie QR, Zhang T, Yu H, Wang B, Ying W, Mruk DD, Silvestrini B, Cheng CY and Xia W: Adjudin attenuates lipopolysaccharide (LPS)- and ischemia-induced microglial activation. J Neuroimmunol 254: 83-90, 2013.

19. Xu C, Hu Y, Hou L, Ju J, Li X, Du N, Guan X, Liu Z, Zhang T, Qin W, et al: $\beta$-Blocker carvedilol protects cardiomyocytes against oxidative stress-induced apoptosis by up-regulating miR-133 expression. J Mol Cell Cardiol 75: 111-121, 2014.

20. Yan A, Cai G, Xia W and Fu Y: Thromboxane A2 receptor antagonist SQ29548 suppresses the LPS-induced release of inflammatory cytokines in BV2 microglia cells via suppressing MAPK and NF- $\mathrm{BB}$ signaling pathways. Mol Med Rep 16: 2491-2496, 2017.

21. Livak KJ and Schmittgen TD: Analysis of relative gene expression data using real-time quantitative PCR and the $2^{-\Delta \Delta C_{\mathrm{T}}}$ method. Methods 25: 402-408, 2001.

22. Wacker MJ, Tevis O, Hanke J, Howard T, Gilbert W and Orr JA: Characterization of thromboxane A2 receptor and TRPV1 mRNA expression in cultured sensory neurons. Neurosci Lett 515: 12-17, 2012.

23. Qian D, Li Z, Zhang Y, Huang Y, Wu Q, Ru G, Chen M and Wang B: Response of mouse zygotes treated with mild hydrogen peroxide as a model to reveal novel mechanisms of oxidative stress-induced injury in early embryos. Oxid Med Cell Longev 2016: 1521428, 2016.

24. Cudd TA and Wood CE: Thromboxane A2 receptor antagonism prevents hormonal and cardiovascular responses to mineral acid infusion. Am J Physiol 267: R1235-R1240, 1994.

25. Rebel AA, Urquhart SA, Puig KL, Ghatak A, Brose SA, Golovko MY and Combs CK: Brain changes associated with thromboxane receptor antagonist SQ 29,548 treatment in a mouse model. J Neurosci Res 93: 1279-1292, 2015.

26. Benndorf RA, Schwedhelm E, Gnann A, Taheri R, Kom G, Didié M, Steenpass A, Ergun S and Böger RH: Isoprostanes inhibit vascular endothelial growth factor-induced endothelial cell migration, tube formation, and cardiac vessel sprouting in vitro, as well as angiogenesis in vivo via activation of the thromboxane $A(2)$ receptor: A potential link between oxidative stress and impaired angiogenesis. Circ Res 103: 1037-1046, 2008.

27. Lopes FM,SchröderR,daFrotaMLJr,Zanotto-FilhoA,MüllerCB, Pires AS, Meurer RT, Colpo GD, Gelain DP, Kapczinski F, et al: Comparison between proliferative and neuron-like SH-SY5Y cells as an in vitro model for Parkinson disease studies. Brain Res 1337: 85-94, 2010

28. Cho GW, Koh SH, Kim MH, Yoo AR, Noh MY, Oh S and Kim SH: The neuroprotective effect of erythropoietin-transduced human mesenchymal stromal cells in an animal model of ischemic stroke. Brain Res 1353: 1-13, 2010.

29. Chakraborty R, Bhullar RP, Dakshinamurti S, Hwa J and Chelikani P: Inverse agonism of SQ 29,548 and ramatroban on thromboxane A2 receptor. PLoS One 9: e85937, 2014.

30. Yang W, Yan A, Zhang T, Shao J, Liu T, Yang X, Xia W and Fu Y: Thromboxane A2 receptor stimulation enhances microglial interleukin-1 $\beta$ and NO biosynthesis mediated by the activation of ERK pathway. Front Aging Neurosci 8: 8, 2016.

31. Yun DH, Song HY, Lee MJ, Kim MR, Kim MY, Lee JS and Kim JH: Thromboxane A2modulates migration, proliferation, and differentiation of adipose tissue-derived mesenchymal stem cells. Exp Mol Med 41: 17-24, 2009.

32. Kumar KH and Khanum F: Hydroalcoholic extract of cyperus rotundus ameliorates $\mathrm{H} 2 \mathrm{O} 2$-induced human neuronal cell damage via its anti-oxidative and anti-apoptotic machinery. Cell Mol Neurobiol 33: 5-17, 2013.

33. Huang YY, Nagata K, Tedford CE, McCarthy T and Hamblin MR: Low-level laser therapy (LLLT) reduces oxidative stress in primary cortical neurons in vitro. J Biophotonics 6: 829-838, 2013. 
34. Jagtap JC, Chandele A, Chopde BA and Shastry P: Sodium pyruvate protects against $\mathrm{H}_{2} \mathrm{O}_{2}$ mediated apoptosis in human neuroblastoma cell line-SK-N-MC. J Chem Neuroanat 26 : 109-118, 2003.

35. Chen H, Yoshioka H, Kim GS, Jung JE, Okami N, Sakata H, Maier CM, Narasimhan P, Goeders CE and Chan PH: Oxidative stress in ischemic brain damage: Mechanisms of cell death and potential molecular targets for neuroprotection. Antioxid Redox Signal 14: 1505-1517, 2011.

36. Miguel F, Augusto AC and Gurgueira SA: Effect of acute vs chronic $\mathrm{H}_{2} \mathrm{O}_{2}$-induced oxidative stress on antioxidant enzyme activities. Free Radic Res 43: 340-347, 2009.

37. D'Amelio M, Cavallucci V and Cecconi F: Neuronal caspase-3 signaling: Not only cell death. Cell Death Differ 17: 1104-1114, 2010.

38. Brentnall M, Rodriguez-Menocal L, De Guevara RL, Cepero E and Boise LH: Caspase-9, caspase-3 and caspase-7 have distinct roles during intrinsic apoptosis. BMC Cell Biol 14: 32, 2013

39. Hsieh CJ, Kuo PL, Hsu YC, Huang YF, Tsai EM and Hsu YL: Arctigenin, a dietary phytoestrogen, induces apoptosis of estrogen receptor-negative breast cancer cells through the ROS/p38 MAPK pathway and epigenetic regulation. Free Radic Biol Med 67: 159-170, 2014.

40. Sui X, Kong N, Ye L, Han W, Zhou J, Zhang Q, He C and Pan H: p38 and JNK MAPK pathways control the balance of apoptosis and autophagy in response to chemotherapeutic agents. Cancer Lett 344: 174-179, 2014

41. Ruffels J, Griffin M and Dickenson JM: Activation of ERK1/2, JNK and PKB by hydrogen peroxide in human SH-SY5Y neuroblastoma cells: Role of ERK1/2 in H2O2-induced cell death. Eur J Pharmacol 483: 163-173, 2004.

42. Filomeni G, Piccirillo S, Rotilio G and Ciriolo MR: p38 ${ }^{\mathrm{MAPK}}$ and ERK1/2 dictate cell death/survival response to different pro-oxidant stimuli via p53 and Nrf2 in neuroblastoma cells SH-SY5Y. Biochem Pharmacol 83: 1349-1357, 2012.
43. Zhuang S, Yan Y, Daubert RA, Han J and Schnellmann RG: ERK promotes hydrogen peroxide-induced apoptosis through caspase-3 activation and inhibition of Akt in renal epithelial cells. Am J Physiol Renal Physiol 292: F440-F447, 2007.

44. Zhuang S, Demirs JT and Kochevar IE: p38 mitogen-activated protein kinase mediates bid cleavage, mitochondrial dysfunction, and caspase- 3 activation during apoptosis induced by singlet oxygen but not by hydrogen peroxide. J Biol Chem 275: 25939-25948, 2000

45. Liu J, Yang L, Tian H and Ma Q: Cathepsin D is involved in the oxygen and glucose deprivation/reperfusion-induced apoptosis of astrocytes. Int J Mol Med 38: 1257-1263, 2016.

46. Wen SH, Ling YH, Liu WF, Qiu YX, Li YS, Wu Y, Shen JT, Xia ZY and Liu KX: Role of 15-F2t-isoprostane in intestinal injury induced by intestinal ischemia/reperfusion in rats. Free Radic Res 48: 907-918, 2014

47. Zhao Z, Hu J, Gao X, Liang H, Yu H, Liu S and Liu Z: Hyperglycemia via activation of thromboxane A2 receptor impairs the integrity and function of blood-brain barrier in microvascular endothelial cells. Oncotarget 8: 30030-30038, 2017.

48. Zhao ZY, Luan P, Huang SX, Xiao SH, Zhao J, Zhang B, $\mathrm{Gu} \mathrm{BB}, \mathrm{Pi} \mathrm{RB}$ and Liu J: Edaravone protects HT22 neurons from $\mathrm{H}_{2} \mathrm{O}_{2}$-induced apoptosis by inhibiting the MAPK signaling pathway. CNS Neurosci Ther 19: 163-169, 2013.

49. Han MH, Park C, Lee DS, Hong SH, Choi IW, Kim GY, Choi SH, Shim JH, Chae JI, Yoo YH and Choi YH: Cytoprotective effects of esculetin against oxidative stress are associated with the upregulation of Nrf2-mediated NQO1 expression via the activation of the ERK pathway. Int J Mol Med 39: 380-386, 2017. 